\title{
SEISMIC RESPONSE FOR BUILDING FRAMES IN THE WETLANDS AREA
}

\author{
Eliatun
}

Assistant Professor, Department of Civil Engineering, Lambung Mangkurat University, Banjarbaru, Indonesia

\section{Darmansyah Tjitradi}

Associate Professor, Department of Civil Engineering, Lambung Mangkurat University, Banjarbaru, Indonesia

\section{Syahril Taufik}

Associate Professor, Department of Civil Engineering, Institute of Science and Technology National, Jakarta, Indonesia

\section{Nadhiya Amalia}

Undergraduate Student, Department of Civil Engineering, Lambung Mangkurat University, Banjarbaru, Indonesia

\begin{abstract}
The objective of this paper is to perform the design practice for the structures of stilt building construction, based on the seismic design methodology. Firstly, the design requirements and design constraints are determined according to the site of the building within the Banjarmasin city of the wetlands area and compared with the other zones. Based on the latest Indonesia earthquake design code, the city of Banjarmasin is in the lightest earthquake hazard area so it is considered to neglect the seismic load in earthquake resistance. Actually, South Kalimantan region, mostly as wetland area, has experienced earthquakes several times. On the entire area, the land has a soft soil condition which has the potential to damage buildings in the event of an earthquake due to the amplification of earthquake vibrations. Then, a practical design chart of the basic earthquake load response spectrum has been analyzed. Apart from that, a design practice of varying soil strata is generally considered by the latest code for earthquake engineering design SNI-1726-2019. The results indicate that the earthquake response spectrum design charts for all areas in the low risk zone, as the soft soil ground strata, affected into the seismic load design of earthquake force should be taking into account for design practice. The base shear for the stilt structure of multy story building should be designed as approximately one thirteith of total weight of the building structure.
\end{abstract}

Keywords: seismic load, earthquake response spectrum, stilt structure, wetlands area 
Cite this Article: Eliatun, Darmansyah Tjitradi, Syahril Taufik and Nadhiya Amalia, Seismic Response for Building Frames in the Wetlands Area, International Journal of Civil Engineering and Technology (IJCIET), 12(6), 2021, pp. 43-53. https://iaeme.com/Home/issue/IJCIET?Volume $=12 \&$ Issue $=6$

\section{INTRODUCTION}

The seismic behavior of a building is directly related to the interaction between the three interconnected systems, which are superstructure, foundation and soil medium surrounding the foundation system [1]. The most significant increase in drift demands occurred in first stories and the results corresponding to fixed-base, stiff and moderate cases are closer to each other with respect to soft soil cases [2] indicated that effect of soil-structure interaction on the seismic performance of new buildings is limited with respect to old buildings [3] examined the seismic performance of empirical buildings with SSI [4] and showed that the seismic performance of buildings varied significantly depending on the soil conditions. The site amplification values estimated by considering the local depth of the bedrock surface layer were generally smaller than the seimic accelaration amplification values from the Indonesian seismic building code 1726-2012, there appears to exist a tendency of lower levels of amplification mean regression, in particular for the soft soil site class according to Delfebriyadi et al. [5]. The estimated response showed and acceptable approximation with the real response, although the response calculated with SHAKE2000 predicted high levels of amplification near the natural frequencies of the soft soil deposit, according to Villalobos and Romanel [6]. Lateral deflection, storey drift, base shear and moment values of fixed base building was found to be lower as compared to flexible base building that suitable foundation system considering the effect of soil stiffness has to be adopted while designing building frames for seismic forces, conducted by Elwi et al. [1]. Based on the local soil conditions of Jakarta, the parametric study on site response analysis has been well conducted by Misliniyati et al. [7]. The variation of property parameters, such as depth of bedrock, shear wave velocity of bedrock, and layer thickness have a significant effect on the response spectra at the ground surface The results from Soesilo et al. [8] show that more than $90 \%$ of Indonesian districts have risk coefficient values between 0.7 and 1.1 at a spectral period of $1.0 \mathrm{~s}$. Specifically, almost all 19 big cities have risk coefficient values ranging between 0.9 and 1.1, both at a spectral period of $0.2 \mathrm{~s}$ and of $1.0 \mathrm{~s}$. The latest seismic design code, also do not provide a design chart of the earthquake design load spectrum response such as the previous Indonesian seismic building [9], mainly for hazard risk assesment according to Sengara [10].

To create a simplified model of the seismic response and their related soil stratas for a related methodology is generated in this paper, which applies the principles of earthquake hazard for loading analysis, internal force identification, and risk impact determination.

\section{PROCEDURES AND METHODS}

This section presents the phase-wise description of the developed seismic static load response methodology. The flow of the method is as shown in Figure 1. Following are the steps of the determining design earthquake load for the building frames.

\subsection{Design Spectrum Response}

The procedure for creating a graphical seismic design response of the selected sites [9], [11] and [12]) according to the following steps:

Step 1: Identify the location of buildings representing the selected sites

Defining the position of the site in Indonesia with the gps coordinates 
Step 2: Determine mapped earthquake acceleration parameters $\left(S_{S}\right.$ and $\left.S_{1}\right)$

Plot the gps coordinates into the support system [13]

Step 3: Determine the Site Coefficient $\left(F_{a}\right.$ and $\left.F_{v}\right)$ within the selected sites

Site Coefficient of short period, $F_{a}$, and long period, $F_{v}$.

Step 4: Calculating Design Spectrum Acceleration Parameters $\left(S_{M S}\right.$ and $\left.S_{M 1}\right)$ using equation

$$
S_{M S}=S_{S} \times F_{v}
$$

and

$$
S_{M 1}=S_{1} \times F_{v}
$$

Step 5: Determining the Response Modification Coefficient $\left(S_{D S}\right.$ and $\left.S_{D 1}\right)$ using equation

$$
S_{D S}=2 / 3 \times S_{M S}
$$

and

$$
S_{D 1}=2 / 3 \times S_{M 1}
$$

Step 6: Developing the charts of the earthquake design spectrum response of building frames depending to the soil strata conditions in the selected sites; rock, hard soil, medium soil and soft soil.

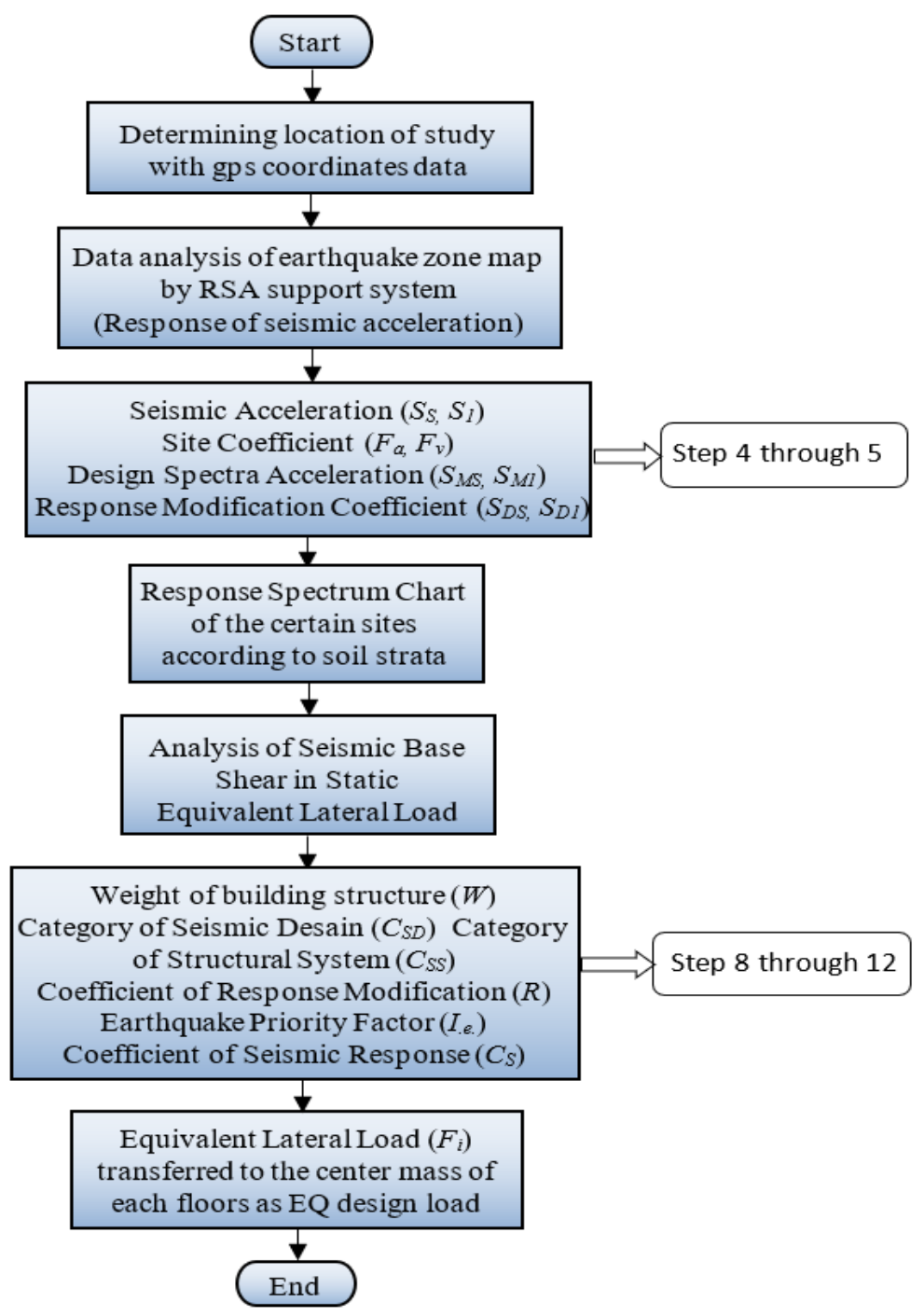

Figure 1 The flow of methodology 


\subsection{Base Shear Analysis}

After creating the charts of the earthquake design response spectrum for each area in the selected sites, it can be analyzed the magnitude of the basic earthquake load at each certain building location. Take the case study of an office building with a 5-storey reinforced concrete stilt structure as in Fig. 2 which will compare the magnitude of the basic earthquake load $(V)$ that will work at each building location in the certain sites, besides that, a relationship will be obtained as a graph and a regression equation plotting of $V$ and $W$. The calculation of the base shear is carried out using the Equivalent Static Method by the following steps:

Step 7: Equivalent Static Lateral Force Analysis using the following sub steps:

Step 7.1 Defining the number of building storeys $(N)$

Step 7.2 Defining the total weight of building structure $(W)$

Step 7.3 Calculating the Fundamental Approach Period $\left(T_{a}\right)$

Step 7.4 Calculating the Upper Limit Coefficient for the period $\left(C_{u}\right)$

Step 7.5 Determine the Fundamental Period of the Structure $(T)$, take $T_{\max }$

Step 8: Determining Category of Seismic Design $\left(C_{S D}\right)$

It is intended to ensure structural details that meet the requirements according to the estimated earthquake intensity. $C_{S D}$ relates to: earthquake hazard level, soil type, as well as the use and function of the building.

Step 9: Determining Category of Structural System $\left(C_{S S}\right)$

Structural system is classified into three levels, respectively, namely; Low ( $C_{S D}$ of A and $\mathrm{B})$, Medium $\left(C_{S D}\right.$ of $\left.\mathrm{C}\right)$ and High $\left(C_{S D}\right.$ of $\mathrm{D}, \mathrm{E}$ and $\left.\mathrm{F}\right)$

Step 10: Determining the Response Modification Factor $(R)$

Earthquake load reduction factor is a value that reduces the amount of earthquake load based on type of designed structure and other supporting structural components. The value of $R$ is range between 3.0 to 8.0.

Step 11: Determining the Seismic Importance Factor $\left(I_{e}\right)$

This factor is determined based on the type of building utilization. Building with risk categories I and II have building priority factor 1.0, for category risk III has a factor of 1.25, and risk category IV has a factor of 1.5.

Step 12: Determining the Seismic Response Coefficient $\left(C_{S}\right)$

Seismic Response Coefficient, $C_{s}$, is calculated using equation

$$
C_{S}=\frac{S_{D S}}{\left(\frac{R}{I_{e}}\right)}
$$

$\mathrm{C}_{\mathrm{s}-\max }=\left|\begin{array}{cc}\frac{\mathrm{S}_{\mathrm{D} 1}}{T \times\left(\frac{\mathrm{R}}{\mathrm{I}_{\mathrm{e}}}\right)} & \text { if } T \leq T_{L} \\ \text { else } & \frac{\mathrm{S}_{\mathrm{D} 1} \times T_{L}}{T^{2} \times\left(\frac{R}{I_{e}}\right)}\end{array}\right| ; C_{S-\min }=0.044 \times S_{D S} \times I_{e} \geq 0.01$

where: $S_{D S} \quad=$ parameter of spectra response accelaration

$R \quad=$ response modification coefficient

$I_{e} \quad=$ seismic importance factor

$T \quad=$ fundamental natural period (sec)

$T_{L} \quad=$ long transition period $(\mathrm{sec})$ 
Step 13: Calculating Base Shear, $V$

Base shear, $V$, is calculated using equation

$$
V=C_{S} \times W
$$

where: $\quad W=$ total weight of the entire building structure $(\mathrm{kN})$

Step 14: Calculating the equivalent static EQ load $\left(F_{i}\right)$ acting at the mass center of the floors [14]

Base shear is then distributed into each floor as lateral point load at beam-column joint (Figure 2), using the following equations; for major axes and for minor axes, according to [9], [15], and [16].

$$
F_{x i}=\frac{W_{i} \times h_{i}^{k}}{\sum W_{i} \times h_{i}^{k}} \times V_{x}
$$

and

$$
F_{y i}=\frac{W_{i} \times h_{i}^{k}}{\sum W_{i} \times h_{i}^{k}} \times V_{y}
$$

where: $F_{x i} \quad=$ lateral point load in major axes $(\mathrm{kN})$

$F_{y i} \quad=$ lateral point load in minor axes $(\mathrm{kN})$

$W_{i} \quad=$ total weight of each storey $(\mathrm{kN})$

$h_{i} \quad=$ column height for each storey $(\mathrm{kN})$

$V_{x} \quad=$ base shear in $\mathrm{x}$-axes $(\mathrm{kN})$

$V_{y} \quad=$ base shear in $y$-axes $(\mathrm{kN})$

$k \quad=$ an exponential related to the structure period $(T)=0.50 \times T+0.75$
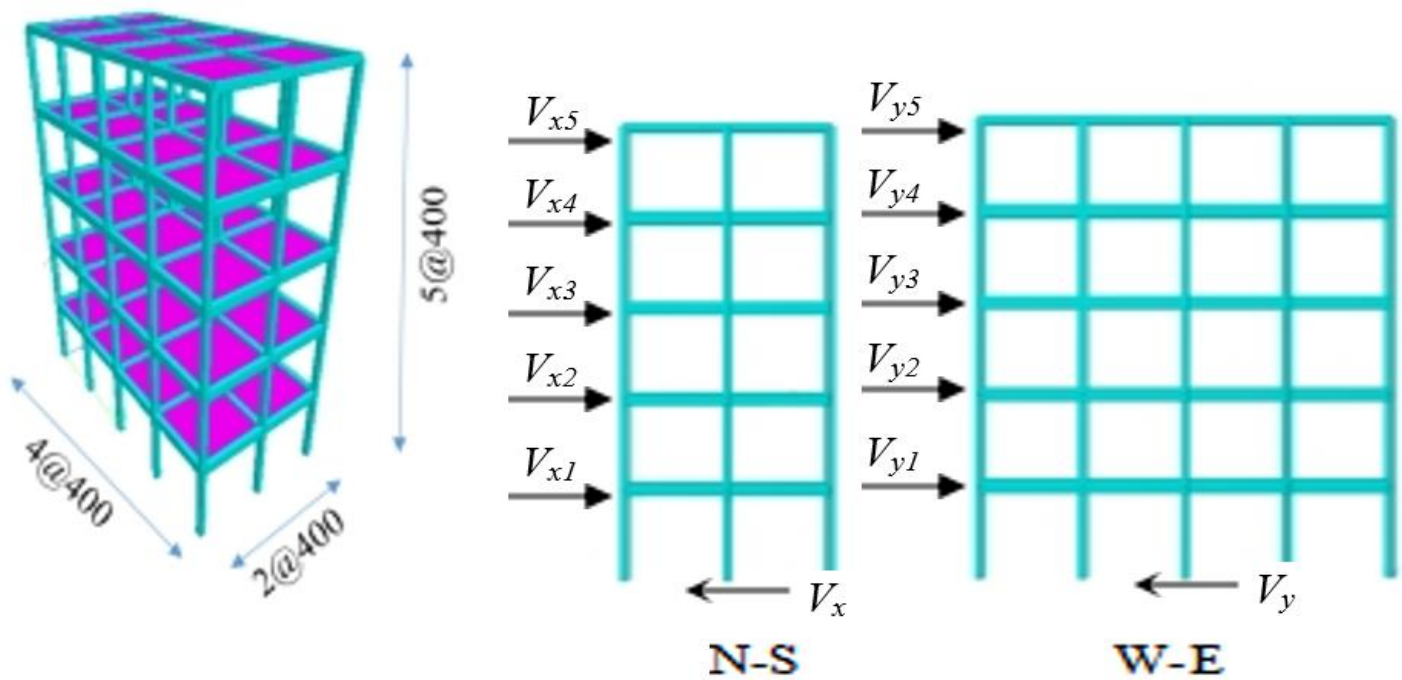

Figure 2 The building model of a 5-storey RC stilt frame structure

\section{RESULTS AND DISCUSSION}

This section presents the seismic design load assessment of a building frame in wetlands region of South Kalimantan, Banjarmasin. The city, Banjarmasin, is situated on the banks of the river Barito with geographic coordinates $3^{\circ} 16^{\prime} 46^{\prime \prime}-3^{\circ} 22^{\prime} 54^{\prime \prime}$ latitude South and 114 $31^{\prime} 40^{\prime \prime}$ - 
$114^{\circ} 39^{\prime} 55^{\prime \prime}$ longitude East. The buildings within this area will be built above deep soft soil strata with earthquake (EQ) risk zone 2.

The other sites, Banjarbaru and Bulungan, have been chosen for taking comparison with the other higher conditions of soil strata and EQ risk categories. The results of the earthquake spectrum response analysis with different EQ risk zones and soil strata conditions were made according to NSA [9], can be seen in Table 1 and plotted in Figures 3 through 5.

Table 1 Earthquake Spectrum Response Analysis

\begin{tabular}{|c|l|c|c|c|c|c|c|c|c|}
\hline $\begin{array}{c}\text { EQ risk } \\
\text { zone }\end{array}$ & \multicolumn{1}{|c|}{ Soil strata } & $\begin{array}{c}\mathbf{P}_{\mathbf{G A}} \\
(\mathbf{g})\end{array}$ & $\begin{array}{c}\mathbf{S}_{\mathbf{s}} \\
(\mathbf{g})\end{array}$ & $\begin{array}{c}\mathbf{S}_{\mathbf{1}} \\
(\mathbf{g})\end{array}$ & $\begin{array}{c}\mathbf{T}_{\mathbf{L}} \\
(\mathbf{s e c})\end{array}$ & $\begin{array}{c}\mathbf{T}_{\mathbf{0}} \\
(\mathbf{s e c})\end{array}$ & $\begin{array}{c}\mathbf{T}_{\mathbf{s}} \\
(\mathbf{s e c})\end{array}$ & $\begin{array}{c}\mathbf{S}_{\mathbf{d s}} \\
(\mathbf{g})\end{array}$ & $\begin{array}{c}\mathbf{S}_{\mathbf{d} 1} \\
(\mathbf{g})\end{array}$ \\
\hline 2 & Soft Soil & 0.052 & 0.102 & 0.052 & 12 & 0.180 & 0.880 & 0.170 & 0.150 \\
\hline 3 & Medium Soil & 0.058 & 0.115 & 0.054 & 12 & 0.150 & 0.750 & 0.120 & 0.090 \\
\hline 4 & Hard Soil & 0.153 & 0.316 & 0.142 & 16 & 0.100 & 0.520 & 0.270 & 0.140 \\
\hline
\end{tabular}

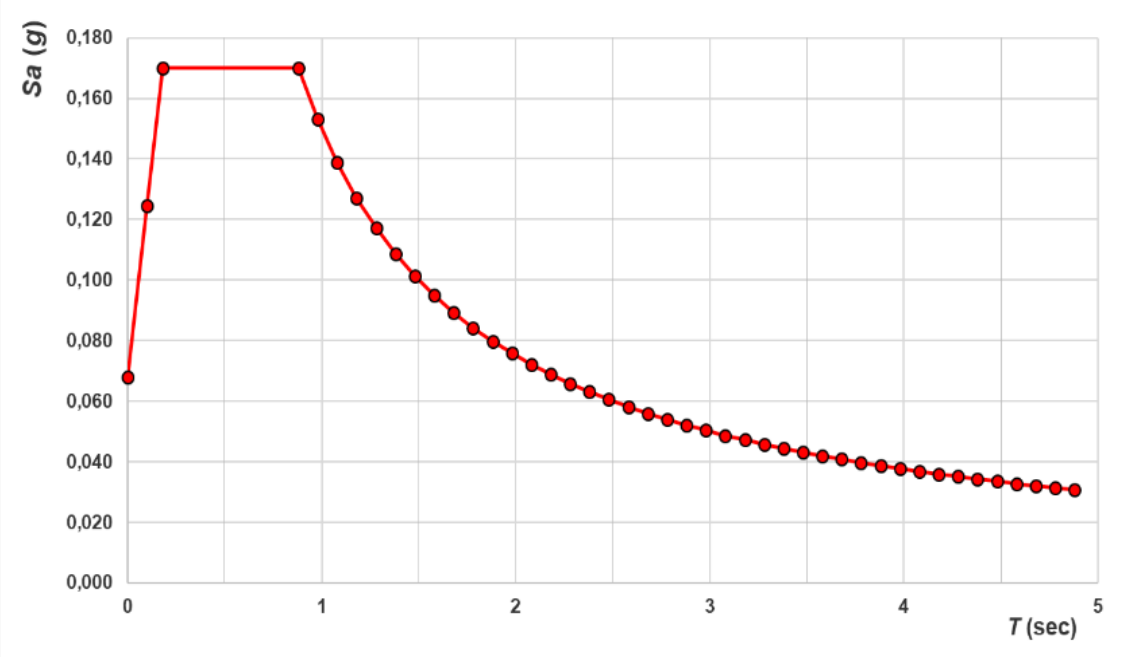

Figure 3 Earthquake Response Spectrum for Soft Soil (SE) in EQ risk zone 2

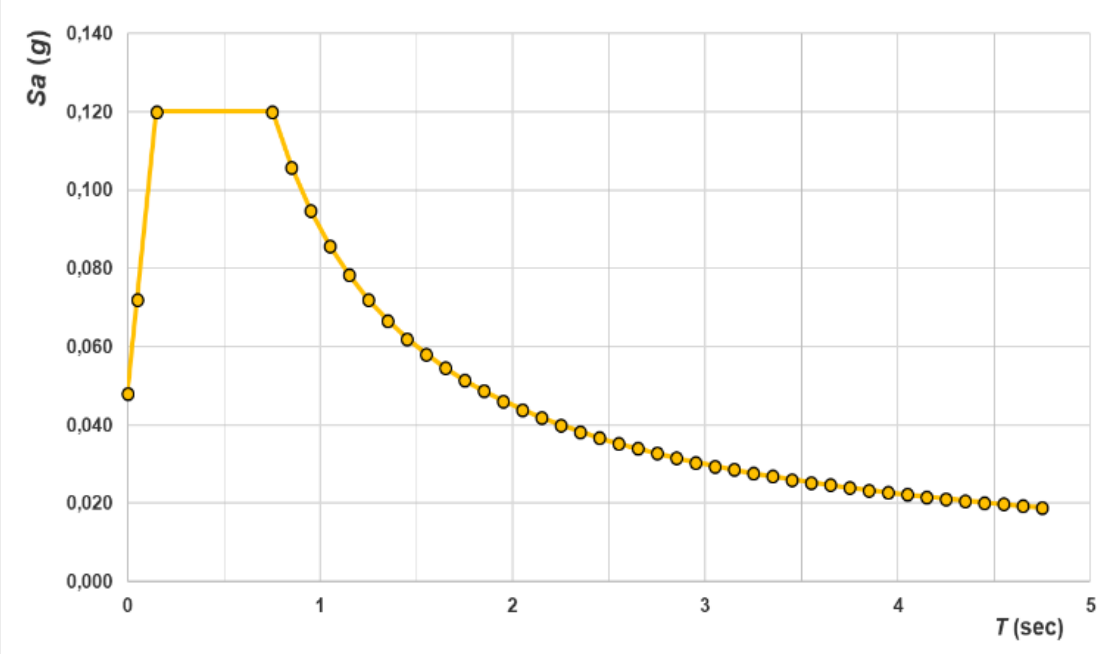

Figure 4 Earthquake Response Spectrum for medium soil (SD) in EQ risk zone 3 


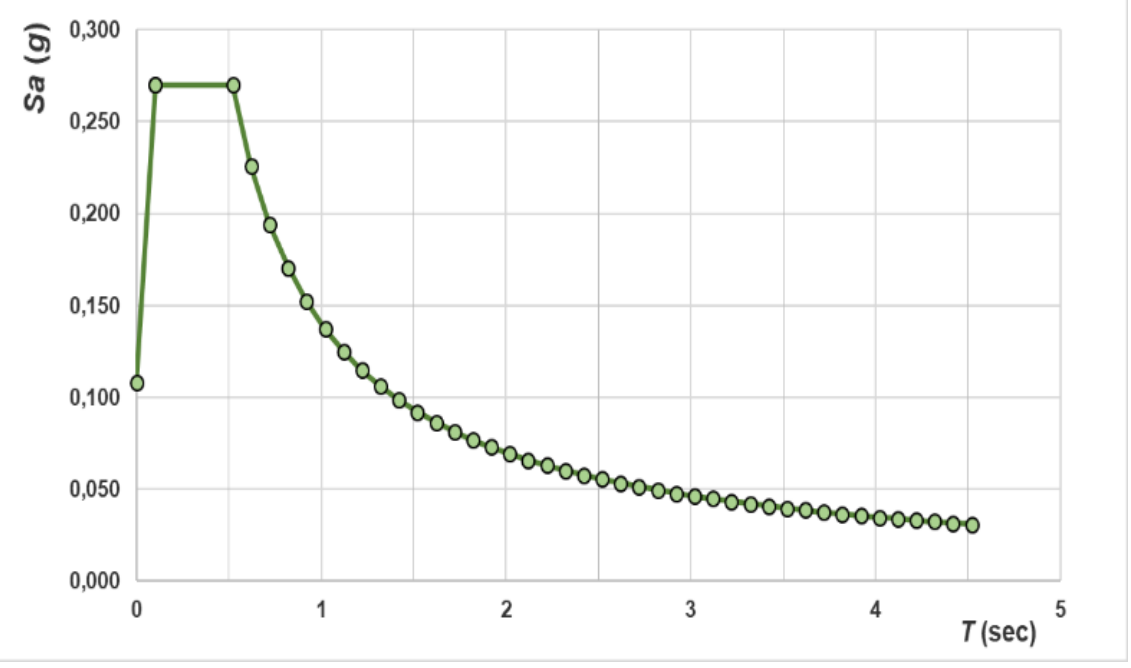

Figure 5 Earthquake Response Spectrum for hard soil (SC) in EQ risk zone 4

The results of the earthquake response spectrum analysis for 66 locations representing the sites within wetlands area, Banjarmasin city, made by using the support system [13]. The response spectrum of the design earthquake for all areas in the city of Banjarmasin has a normal behavior, which the softer the soil strata conditions, the greater the basic earthquake response. The maximum values of earthquake response spectrum with soft soil (SE) conditions is plotted into Figure 3. As comparison with Banjarbaru site, Figure 4 shows the chart of response spectrum for medium soil in earthquake (EQ) risk zone 3. Also, the higher EQ risk zone 4 with hard soil condition, in Bulungan, East Kalimantan, it is plotted the response into Figure 5. The analysis of three different conditions according to total weight of the building is conducted to determine the value of total base shear, $V$, as detailed in Table 1.

Table 2 Results of Base Shear Analysis

\begin{tabular}{|c|c|c|c|}
\hline \multirow{2}{*}{$\begin{array}{c}\text { Seismic } \\
\text { Weight of } \\
\text { Building (W) }\end{array}$} & $\begin{array}{c}|c| \\
\text { Soft soil } \\
\text { Zone 2 }\end{array}$ & $\begin{array}{c}\text { Medium Soil } \\
\text { Zone 3 }\end{array}$ & $\begin{array}{c}\text { Hard Soil } \\
\text { Zone 4 }\end{array}$ \\
\hline$(\mathrm{kN})$ & $(\mathrm{kN})$ & $(\mathrm{kN})$ & $(\mathrm{kN})$ \\
\hline 0 & 0 & 0 & 0 \\
\hline 50,000 & 1,700 & 1,745 & 1,730 \\
\hline 75,000 & 2,550 & 2,618 & 2,595 \\
\hline 100,000 & 3,400 & 3,490 & 3,460 \\
\hline 125,000 & 4,250 & 4,363 & 4,325 \\
\hline 150,000 & 5,100 & 5,235 & 5,190 \\
\hline 175,000 & 5,950 & 6,108 & 6,055 \\
\hline 200,000 & 6,800 & 6,980 & 6,920 \\
\hline 225,000 & 7,650 & 7,853 & 7,785 \\
\hline 250,000 & 8,500 & 8,725 & 8,650 \\
\hline 275,000 & 9,350 & 9,598 & 9,515 \\
\hline 300,000 & 10,200 & 10,470 & 10,380 \\
\hline 325,000 & 11,050 & 11,343 & 11,245 \\
\hline 350,000 & 11,900 & 12,215 & 12,110 \\
\hline
\end{tabular}

Based on the results of the analysis of the basic seismic force on the building structure model in the wetland area (Figures 3 ) and the other sites in medium and hard soil conditions, Banjarbaru and Bulungan, as depicted in in Figures 4-5, using the equivalent static method, it can be seen that Banjarmasin city and other sites has the seismic design category of $C_{S D}$ as 
category $\mathrm{C}$ and the allowable structural system is the Intermediate Moment Resisting Frame (IMRF). It is also obtained a practical design chart of the basic earthquake load based on the weight of the building as in Figure 6. Based on the chart data, the regression equation can be obtained along with the coefficient of determination $\left(R^{2}\right)$ for each region in South Kalimantan with different soil strata. By analyzing the design chart of the basic earthquake load in Table 2 and Figures 3 - 5, it can be seen that for the medium soil strata with intermediate EQ hazard zone has slightly the largest base shear of seismic design load. The ratios of $V_{S C}$ and $V_{S D}$ compared with $V_{S E}$ are 1.0265 and 1.0176 , respectively.

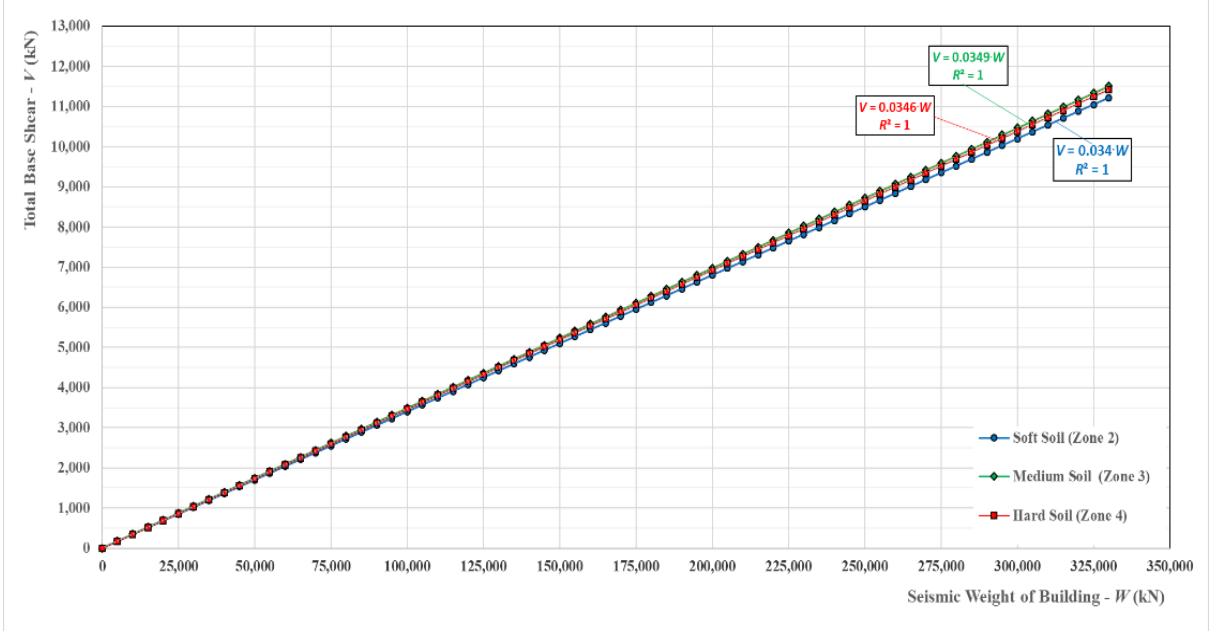

Figure 6 Design chart of base shear in different soil strata under varying EQ risk zone

The regression equations of seismic response coefficient, $C_{\mathrm{s}}$, for each zone obtained to determine the base shear based on the building weight $(W)$ in different soil strata and basic seismic coefficient, $C_{B S}$, is depicted in Table 3 as follows:

Table 3 Seismic response coefficient

\begin{tabular}{|l|l|c|l|l|}
\hline \multicolumn{1}{|c|}{ Soil strata } & \multicolumn{1}{c|}{$\begin{array}{c}\text { EQ hazard } \\
\text { classification }\end{array}$} & \multicolumn{1}{c|}{$\boldsymbol{C}_{\boldsymbol{s}}$} & \multicolumn{1}{c|}{$\boldsymbol{C}_{\boldsymbol{S S}}$} & $\begin{array}{c}\text { Structural } \\
\text { System }\end{array}$ \\
\hline Soft Soil & Low risk (zone 2) & 0.0340 & Medium, C & IMRF \\
\hline Medium Soil & Medium risk (zone 3) & 0.0349 & Medium, C & IMRF \\
\hline Hard Soil & High risk (zone 4) & 0.0346 & Medium, C & IMRF \\
\hline
\end{tabular}

Based on Table 2, the base shear values for different soil strata in the conditions of various EQ hazard risk is quite similar in conservative approach. The coeficient of basic seismic response, $C_{S S}$, is categorized as $\mathrm{C}$, medium design response by using the structure system of intermediate moment resisting frame structure (IMRF). After the base shear, $V$, is obtained, then the design load will be distributed along the height of the building structure into equivalent static lateral point loads acting at the center of mass of the floors. Samples were taken of buildings in Banjarmasin area as the sub soft soil and obtained the results of the distribution of seismic base shear according to Eqs. 5 and 6, which can be seen in Tables 4 and 5 and Figures 7 and 8. 
Eliatun, Darmansyah Tjitradi, Syahril Taufik and Nadhiya Amalia

Table 4 Distribution of the base shear in N-S axes

\begin{tabular}{|c|c|c|c|}
\hline Storey & $\mathbf{h}_{\mathbf{i}}(\mathbf{m})$ & $\mathbf{W}_{\mathbf{i}}(\mathbf{k N})$ & $\mathbf{F}_{\mathbf{i y}}(\mathbf{k N})$ \\
\hline 5 & 20.00 & 135.424 & 9.118 \\
\hline 4 & 16.00 & 362.576 & 18.886 \\
\hline 3 & 12.00 & 362.576 & 13.566 \\
\hline 2 & 8.00 & 362.576 & 8.510 \\
\hline 1 & 4.00 & 362.576 & 3.835 \\
\hline Total & & $1,585.728$ & 53.915 \\
\hline
\end{tabular}

Table 5 Distribution of the base shear in W-E axes

\begin{tabular}{|c|c|c|c|}
\hline Storey & $\mathbf{h}_{\mathbf{i}}(\mathbf{m})$ & $\mathbf{W}_{\mathbf{i}}(\mathbf{k N})$ & $\mathbf{F}_{\mathbf{i y}}(\mathbf{k N})$ \\
\hline 5 & 20.00 & 225.707 & 15.196 \\
\hline 4 & 16.00 & 604.293 & 31.476 \\
\hline 3 & 12.00 & 604.293 & 22.610 \\
\hline 2 & 8.00 & 604.293 & 14.184 \\
\hline 1 & 4.00 & 604.293 & 6.392 \\
\hline Total & & $2,642.879$ & 89.858 \\
\hline
\end{tabular}

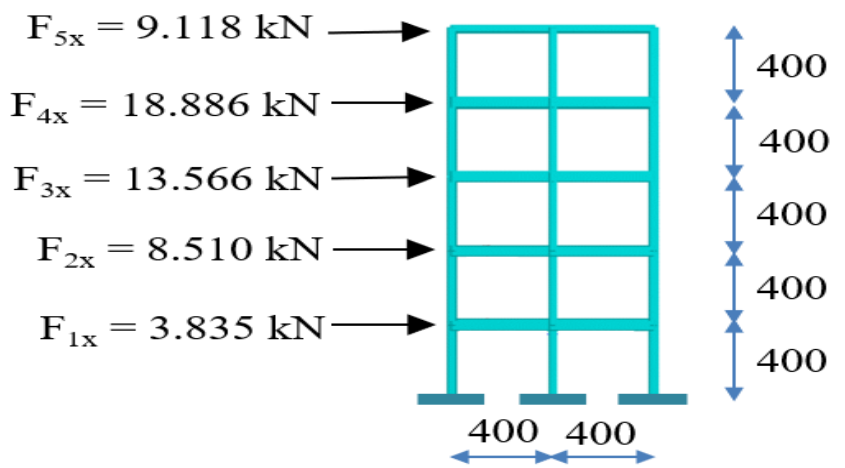

(West - East orientation)

Figure 7 Distribution of base shear in major axes

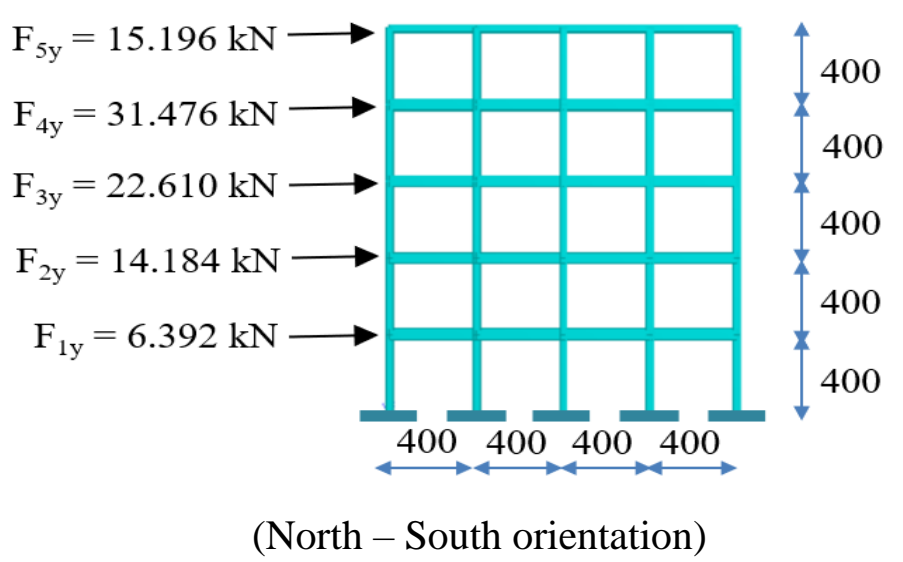

Figure 8 Distribution of base shear in minor axes

According to designed base shear and having shear distribution into each floor for a 5 story building for both major and minor axis, as depicted in Table 6 . 
Table 6 Designed seismic load for 5 story building

\begin{tabular}{|c|c|c|c|c|c|c|}
\hline \multirow{2}{*}{$\mathbf{h}_{\mathbf{i}}(\mathbf{m})$} & \multicolumn{2}{|c|}{$\begin{array}{c}\text { Low EQ zone } \\
(\text { Soft Soil) }\end{array}$} & \multicolumn{2}{c|}{$\begin{array}{c}\text { Medium EQ zone } \\
\text { (Medium soil) }\end{array}$} & \multicolumn{2}{c|}{$\begin{array}{c}\text { High EQ zone } \\
(\text { Hard soil) }\end{array}$} \\
\cline { 2 - 7 } & $\mathbf{F}_{\mathbf{x i}}(\mathbf{k N})$ & $\mathbf{F}_{\mathbf{y i}}(\mathbf{k N})$ & $\mathbf{F}_{\mathbf{x i}} \mathbf{( k N )}$ & $\mathbf{F}_{\mathbf{y i}}(\mathbf{k N})$ & $\mathbf{F}_{\mathbf{x i}}(\mathbf{k N})$ & $\mathbf{F}_{\mathbf{y i}}(\mathbf{k N})$ \\
\hline 20.00 & 9.118 & 15.196 & 9.485 & 15.809 & 9.291 & 15.486 \\
\hline 16.00 & 18.886 & 31.476 & 19.517 & 32.528 & 19.224 & 32.041 \\
\hline 12.00 & 13.566 & 22.610 & 13.899 & 23.165 & 13.790 & 22.983 \\
\hline 8.00 & 8.510 & 14.184 & 8.614 & 14.356 & 8.633 & 14.388 \\
\hline 4.00 & 3.835 & 6.392 & 3.802 & 6.336 & 3.877 & 6.461 \\
\hline Total & 53.915 & 89.858 & 55.316 & 92.193 & 54.815 & 91.359 \\
\hline
\end{tabular}

\section{CONCLUSION}

The earthquake response analysis using the equivalent static method, it can be concluded as follows: the design graph of the earthquake design response spectrum representing different locations in wetlands and medium soil strata has been obtained. Regression equations and practical design graphs for building base shear seismic loads have been obtained for buildings on soft soils in the wetlands and medium soil strata nearby. The regression equation for each sub-district obtained to determine the base earthquake load, $V$, based on the building weight $(W)$ for different soil strata; soft soil zone; $V=0.0340 \times W$, medium soil zone: $V=0.0349 \times W$ $\left(V_{\max }\right)$, and hard soil zone: $V=0.0346 \times W$. The design earthquake in the soil strata conditions, has been presented for 5 story building frame for three zones of EQ hazard in South and East Kalimantan. Banjarmasin city is included in the seismic design category of $\mathrm{C}$, which is a geotechnical investigation shall be conducted, and shall include an evaluation of all of the following potential geologic and seismic hazards; slope instability, liquefaction, total and differential settlement. The building structure system allowed for the buildings within wetlands area in deep soft soil to apply in design is the Intermediate Moment Resisting Frame System (IMRF) with reinforcement detailing in consideration of strong column - weak beam approach.

The results indicate that the earthquake response spectrum design charts for all areas in the low risk zone, as the soft soil ground strata, affected into the seismic load design of earthquake force should be taking into account for design practice. The seismic response of soft soil strata under low risk zone is nearly similar with that of the sites in high EQ risk and hard soil conditions. The base shear for the stilt structure of multy story building should be designed as approximately one thirtieth of total weight of the building structure.

\section{REFERENCES}

[1] Elwi, M., Bassman Muhammed and Nada Alhussiny, Evaluation of Soil-structure Interaction for Structures Subjected to Earthquake Loading with Different Types of Foundation, MATEC Web of Conferences 162, 04026, 1-3, https://doi.org/ 10.1051/ matecconf/201816204026, 2018.

[2] Ibrahim Oz, Sevket Murat Senel, Mehmet Palanci and Ali Kalkan, Effect of Soil-Structure Interaction on the Seismic Response of Existing Low and Mid-Rise RC Buildings, Applied Science, 10, 8357; 1-21, doi:10.3390/app10238357, 2020.

[3] Fatahi, B.; Tabatabaiefar, H.R.; and Samali, B.. Performance Based Assessment of Dynamic Soil-Structure Interaction Effects on Seismic Response of Building Frames. In Proceedings of the GeoRisk 2011: Geotechnical Risk Assessment and Management, Atlanta, GA, USA, 26-28 June 2011; 344-351, 2011. 
[4] Federal Emergency Management Agency (FEMA), 2009. Recommended Seismic Provisions for New Buildings and Other Structures; FEMA P-750-1/2009; Federal Emergency Management Agency (FEMA): Washington, DC, USA.

[5] Delfebriyadi, Masyhur Irsyam, Bigman M. Hutapea, Iswandi Imran \& Muhammad Asrurifak, Determination of Site Amplification Deep Soil Layers using 1-D Site Response Analysis (Case Study: Jakarta City, Indonesia). Journal Engineering Technology Science, 51: 6, 824-838, DOI: 10.5614/j.eng.technol.sci.2019.51.6.6, 2019.

[6] Villalobos, M., and Celso Romanel, Seismic Response of Soft Soil Deposit Using Simplified Models, E3S Web of Conferences 92, 16008 IS-Glasgow, https://doi.org/10.1051/e3sconf/20199216008, 2019.

[7] Misliniyati, R., Sahadewa, A., Hendriyawan \& Irsyam, M., Parametric Study of OneDimensional Seismic Site Response Analyses Based on Local Soil Condition of Jakarta, Journal of Engineering and Technological Sciences, 51(3), 392-410, 2019.

[8] Soesilo, Joko et al., Reconstruction of Meratus by Subduction Modelling Around Java, Borneo and Celebes Islands, J. Phys.: Conf. Ser. 1153 012015, 1-7, 2019.

[9] NSA, National Standardization Agency. SNI 03-1726-2019, Indonesia Standard Design Code for Earthquake Resistance for Building Construction, Jakarta, BSN, 2019. (In Indonesian)

[10] Sengara, I.W. et.al. Development of Risk Coefficient for Input to New Indonesian Seismic Building Codes”, Journal of Engineering Technology Science, vol. 48, no. 1, 49-65, 2016.

[11] Farlianti, S. and Sapta, S., Calculation of the Response Spectra of the Palembang City Earthquake Acceleration Based on SNI 1726;2019 as a Revision to SNI 1726;2012, Teknika, vol 6, no. 2, 167-177, 2019.

[12] Finley, A.C., Seismic Loads (Guide to the Seismic Load Provisions of ASCE 7-10); ASCE Press, 2015.

[13] Civil Works Agency, Support System for Design Spectrum Response in Indonesia, Ministry of Public Works, Jakarta, online web version; http://rsa.ciptakarya.pu.go.id/2021/, 2019.

[14] Adamo, Z. et.al.. On the Distribution in Height of Base Shear Forces in Linear Static Analysis of Base-Isolated Structures, Buildings, 10, 197, MDPI, Basel, Switzerland, 2020.

[15] Aksoylu, C., Mobark, A., Arslan, M. H., \& Erkan, I. H. A comparative study on ASCE 7-16, TBEC-2018 and TEC-2007 for reinforced concrete buildings. Revista de La Construccion, 19(2), 282-305. https://doi.org/10.7764/RDLC.19.2.282, 2020

[16] Mark, A., Enrique, H-M. and Dimitrios, V., Design of Reinforced Concrete Buildings for Seismic Performance (Boca Raton : Taylor \& Francis Group, LLC), 2019 